\title{
Pengaruh Pendidikan Gizi Berbasis Theory of Planned Behavior untuk Mempromosikan Pembatasan Konsumsi Fast Food pada Siswi
}

\section{The Effectiveness of Nutrition Education Based on Theory of Planned Behavior to Promote Limited Fast Food Consumption in Girl Students}

\author{
Wuri Rizki Handarbeny*1, Trias Mahmudiono ${ }^{1}$
}

\begin{abstract}
ABSTRAK
Latarbelakang: Gencarnya promosi fast food menimbulkan persepsi bahwa makanan cepat saji merupakan tren dikalangan remaja. Kebiasaan konsumsi makanan cepat saji yang mempunyai tinggi kalori namun rendah zat gizi menimbulkan masalah gizi lebih dan defisiensi zat gizi mikro pada remaja.

Tujuan: Tujuan penelitian ini dilakukan untuk mengetahui pengaruh pendidikan gizi berbasis Theory of Planned Behavior terhadap perubahan pengetahuan, sikap, norma subyektif, perceived behavioral control, intensi, dan konsumsi membatasi fast food pada siswi di SMA Negeri 2 Sidoarjo.

Metode: Penelitian ini dilaksanakan dengan metode quasy experimental pada 32 siswi (16 siswi kelompok kontrol dan 16 siswi kelompok perlakuan) dipilih menggunakan simple random sampling. Pendidikan gizi berbasis TPB dilakukan selama 4 sesi yiatu sesi sikap, norma subyektif, PBC, dan intensi. Kuesioner penelitian yang digunakan untuk meneliti berbasis TPB. Penilaian dilakukan dua kali, yaitu sebelum dan 3 minggu setelah edukasi. Data dianalisis secara deskriptif, uji Mann Whitney dan Wilcoxon Signed Ranks.

Hasil: Berdasarkan hasil penelitian bahwa pendidikan gizi berbasis theory of planned behavior mempengaruhi pengetahuan $(p<0,001)$, sikap $(p<0,001)$, norma subyektif $(p<0,002)$, perceived behavioral control $(p<0,001)$, dan intensi $(p<0,001)$ tetapi tidak mempengaruhi perilaku siswi untuk membatasi fast food $(\mathrm{p}=0,570)$.

Kesimpulan: Pendidikan gizi berbasis TPB dapat mempengaruhi sikap, norma subyektif, PBC, dan intensi tetapi tidak merubah perilaku membatasi fast food. Dengan demikian maka diperlukan pendidikan gizi yang berkelanjutan agar dapat merubah suatu perilaku pembatasan fast food.
\end{abstract}

Kata Kunci: fast food, theory of planned behavior, pengetahuan, sikap, norma subyektif 


\section{ABSTRACT}

Background: The incessant promotion of fast food make a perception that fast food is a trend among teenager. Fast food consumption habits that have high calorie but low nutrients will causes nutritional problems in adolescents.

Objectives: The purpose of this study aimed to determine effect of nutritional education based on theory of planned behavior to change knowledge, attitude, subjective norms, perceived behavioral control, intention, and limited fast food consumption among female students in Sidoarjo.

Methods: This study was interventional quasi-experimental research. 32 female students (each 16 female students for interventional group and 16 female students for control group), were selected by simple random sampling. The education was provided based on theory of planned behavior in four sessions. The researcher-made questionnaire based on theory of planned behavior used for data collection. The questionnaire was completed by the students twice, before and three weeks after the implementation of nutritional education. Data were analyze using descriptive statistics, MannWhitney, and Wilcoxon Signed Ranks.

Result: The results of this study show nutrition education based on theory of planned behavior influence knowledge $(p<0.001)$, attitude $(p<0.001)$, subjective norms $(p=0.002)$, perceived behavioral control ( $p<0.001)$, intention ( $p<0.001)$, but doesn't influence limited fast food consumption $(p=0.570)$. Conclusion: Nutritional education based on the theory of planned behavior influence knowledge, attitude, subjective norms, perceived behavioral control, and intention, but not effect to limited fast food consumption. So, nutrition education designed based on TPB effective to be implementation of health promotion.

Keywords: fast food, theory of planned behavior, knowledge, attitude, subjective norms

\footnotetext{
*Koresponden:

wuri.airlangga@gmail.com

${ }^{1}$ Departemen Gizi Kesehatan, Fakultas

Kesehatan Masyarakat-Universitas Airlangga
}

\section{PENDAHULUAN}

Masalah gizi lebih merupakan salah satu masalah kesehatan pada remaja. Masalah gizi timbul ketika terjadi kesalahan dalam konsumsi makanan. Kesalahan dalam konsumsi makanan pada remaja menyebabkan ketidaksesuaian antara intake dengan kecukupan gizi yang direkomendasikan ${ }^{[1]}$.

Tren konsumsi makanan cepat saji pada remaja yang dijadikan dietary habits akan menimbulkan dampak terhadap kurangnya keragaman makanan. Menurut penelitian di Riyadh menunjukkan bahwa fast food merupakan komponen penting pola makan remaja [2]. Menurut Asian Journal of Clinical Nutrition, Fast food banyak diminati remaja perempuan, sebesar $51,5 \%$ remaja perempuan lebih banyak mengkonsumsi fast food dibandingkan remaja laki-laki ${ }^{[3]}$. Fast food merupakan makanan yang mempunyai tinggi kalori, lemak, gula, dan natrium, sehingga fast food yang dikonsumsi setiap hari akan berdampak pada kualitas diet yang rendah ${ }^{[5]}$ [6]. Kualitas diet seseorang akan berdampak terhadap masalah gizi dan kesehatan, seperti obesitas, diabetes, PJK, dan hipertensi ${ }^{[7]}$. Sebagai upaya preventif masalah gizi dan kesehatan maka diperlukan suatu pendidikan gizi. Pendidikan gizi dapat dilakukan berbasis theory of planned behavior (TPB). Pendidikan gizi berbasis TPB efektif dalam merubah niat dan perilaku. Efektivitas pendidikan gizi berbasis TPB dibuktikan oleh penelitian di Iran yang bertujuan meningkatkan konsumsi susu pada anak usia sekolah, hasil penelitian 
Tabel 1. Rincian Sesi Pendidikan Gizi

\begin{tabular}{|c|c|c|c|c|}
\hline Sesi & Tujuan Sesi & Deskripsi Aktivitas Pendidikan Gizi & Waktu & Metode \\
\hline \multirow[t]{4}{*}{1} & $\begin{array}{l}\text { Meyakinkan } \\
\text { outcome } \\
\text { perilaku } \\
\text { membatasi }\end{array}$ & $\begin{array}{l}\text { 1. Peneliti memberikan pertanyaan kepada siswa, } \\
\text { lalu siswa menuliskan macam-macam fast food } \\
\text { yang biasa dikonsumsi, alasan mengkonsumsi } \\
\text { fast food, dan waktu mengkonsumsi fast food. }\end{array}$ & 10 menit & Brainstorming \\
\hline & $\begin{array}{l}\text { konsumsi } \\
\text { fast food }\end{array}$ & $\begin{array}{l}\text { 2. Peneliti membahas macam-macam fast food } \\
\text { yang umumnya dikonsumsi siswa berdasarkan } \\
\text { hasil brainstorming, lalu menjelaskan besar } \\
\text { kalori pada macam-macam fast food }\end{array}$ & 10 menit & Diskusi \\
\hline & & $\begin{array}{l}\text { 3. Peneliti menunjukkan besar kalori, lemak, gula, } \\
\text { dan garam pada fast food secara visual }\end{array}$ & 15 menit & Praktikum \\
\hline & & $\begin{array}{l}\text { 4. Peneliti menjelaskan efek konsumsi fast food } \\
\text { terhadap kesehatan. }\end{array}$ & 15 menit & Diskusi \\
\hline 2 & $\begin{array}{l}\text { Meyakinkan } \\
\text { outcome } \\
\text { positif } \\
\text { ketika } \\
\text { membatasi } \\
\text { fast food }\end{array}$ & $\begin{array}{l}\text { 1. Peneliti memberikan permainan tentang } \\
\text { persamaan kalori pada fast food dengan } \\
\text { aktivitas fisik yang harus dilakukan agar kalori } \\
\text { tidak disimpan tubuh terlalu banyak. Peneliti } \\
\text { menunjukkan manfaat membatasi fast food, } \\
\text { seperti intake kalori tidak berlebihan sehingga } \\
\text { berat badan ideal, terbebas dari penyakit- } \\
\text { penyakit degeneratif dan produktivitas remaja } \\
\text { akan optimal }\end{array}$ & 10 menit & $\begin{array}{l}\text { Permainan dan } \\
\text { diskusi }\end{array}$ \\
\hline \multirow[t]{2}{*}{3} & $\begin{array}{l}\text { Membentuk } \\
\text { norma } \\
\text { subyektif }\end{array}$ & $\begin{array}{l}\text { 2. Menugaskan siswi untuk mengedukasi } \\
\text { lingkungan sosial melalui perannya sebagai } \\
\text { menjadi nutrition educator }\end{array}$ & 60 menit & $\begin{array}{l}\text { Praktik atau } \\
\text { presentasi }\end{array}$ \\
\hline & & $\begin{array}{l}\text { 3. Membentuk kelompok melalui media sosial } \\
\text { untuk saling memberikan motivasi sehingga } \\
\text { terwujud lingkungan sosial yang kondusif untuk } \\
\text { merubah perilaku membatsi fast food. }\end{array}$ & $\begin{array}{l}\text { Setiap hari } \\
\text { (waktu } \\
\text { menyesuai } \\
\text { kan) }\end{array}$ & $\begin{array}{l}\text { Chatting } \\
\text { melalui media } \\
\text { sosial }\end{array}$ \\
\hline
\end{tabular}

4. Mengemban 1. Identifikasi inhibitor factor/kendala dalam 30 menit Brainstorming gkan membatasi fast food seperti keinginan untuk perceived menghabiskan waktu di restoran cepat saji, behavioral kebiasaan konsumsi fast food dan ajakan dari kontrol lingkungan sosial ke restoran fast food

2. Membuat kesepakatan bersama dengan membuat strategi untuk menghadapi inhibitor 15 menit Diskusi factor

3. Peneliti memberikan motivasi untuk membatasi fast food dan siswa menulis pada report book 15 menit Diskusi tentang capaian-capaian yang telah dilakukan dalam upaya untuk membatasi konsumsi fast food

5. Implementa
si intensi

1. Review materi edukasi mengenai fast food dan 20 menit Diskusi implementasi pembatasan fast food.

2. Peneliti melakukan diskusi terkait implementasi 20 menit Diskusi intensi yang telah ditulis oleh siswa pada report book pada sesi sebelumnya.

3. Mengidentifikasi kendala ketika mengimplementasikan pembatasan fast food 20 menit Diskusi 
tersebut menunjukkan edukasi dapat meningkatkan sikap $(p<0,001)$, norma subyektif $(p<0,001)$, perceived behavioral control $(p<0,001)$, niat $(p<0,001)$, dan konsumsi susu $(p=0,03)^{[8]}$. Efektivitas edukasi berbasis TPB dibuktikan dengan penelitian yang dilakukan di Iran yang menunjukkan bahwa pendidikan gizi pada remaja perempuan dapat meningkatkan sikap $(p<0,001)$, norma subyektif $(p<0,001)$, perceived behavioral control $(p<0,001)$, dan niat $(p<0,001)$ sebagai tindakan preventif pencegahan hipertensi ${ }^{[9]}$.

Berdasarkan efektivitas pendidikan gizi berbasis TPB maka penelitian ini didesain, diimplementasikan, dan dievaluasi berbasis TPB untuk merubah sikap dan norma subyektif terhadap fast food berlebih, perceived behavioral control, niat, dan perilaku pembatasan konsumsi fast food pada siswi di SMA Negeri 2 Sidoarjo.

\section{METODE}

Penelitian ini dilakukan menggunakan metode quasy experimental . Penentuan jumlah responden menggunakan rumus lemeshow, sehingga didapatkan jumlah 32 siswi (16 siswi kelompok kontrol dan 16 siswi kelompok perlakuan) yang dipilih secara acak (simple random sampling). Tetapi terdapat 3 siswi yang drop out, sehingga pada akhirnya terdapat 29 siswi sekolah menengah atas, yaitu 14 siswi kelompok kontrol dan 15 siswi kelompok perlakuan. Penilaian dilakukan 2 kali, yaitu sebelum dan sesudah perlakuan. Kuesioner sebagai instrumen penilai didesain berbasis TPB dengan skala likert 1-7. Penilaian meliputi pengukuran status gizi (indikator IMT/umur) dan pemilihan gambar sesuai gambaran tubuh yang dipersepsikan, dikategorikan positif jika terdapat kesesuaian antara status gizi dan persepsi mengenai gambaran tubuhnya dan dikategorikan negatif jika tidak terdapat kesesuaian (positif dan negatif skala nominal), kuesioner usia (skala rasio) dan uang saku (skala nominal), pengetahuan (10 soal skala rasio), sikap (7 soal skala rasio), norma subyektif (6 soal skala rasio), perceived behavioral control (4 soal skala rasio), dan niat (3 soal skala rasio).

Intervensi berupa pendidikan gizi didesain berbasis TPB. Pendidikan gizi disampaikan oleh peneliti sebagai educator sebanyak 4 sesi dengan durasi 60 menit per sesi. Rincian edukasi dijelaskan oleh tabel 1.

\section{HASIL DAN PEMBAHASAN}

Hasil dari background factor respon dalam penelitian ini meliputi usia, uang saku, dan body image. Distribusi usia respon adalah 15-18 tahun. Menurut penelitian yang di lakukan di Iran menunjukkan bahwa fast food banyak dikonsumsi remaja yang berusia 15-19 tahun ${ }^{[4]}$. Konsumsi fast food banyak dilakukan remaja karena pada usia tersebut remaja mempunyai kesenangan pada makanan yang dianggap tren oleh teman sebaya ${ }^{[2]}$. Rata-rata uang saku yang didapat oleh responden adalah Rp. 346.895 per bulan. Sebesar $62,5 \%$ kelompok kontrol mendapatkan uang saku diatas rata-rata, sedangkan pada kelompok perlakuan sebesar $75 \%$ mendapatkan uang saku diatas rata-rata. Berdasarkan penelitian mengenai konsumsi fast food pada siswa di sekolah menunjukkan konsumsi fast food banyak dilakukan oleh siswa yang mempunyai uang saku diatas rata-rata ${ }^{[10]}$. Apabila remaja mempunyai uang saku lebih untuk dibelanjakan, maka ia lebih berpeluang untuk mengkonsumsi banyak makanan cepat saji ${ }^{[18]}$.

Persepsi mengenai gambaran tubuh pada remaja dapat dipengaruhi oleh media massa, orang tua, dan peer group [11]. Berdasarkan hasil penelitian ini menunjukkan bahwa kedua kelompok mempunyai body image positif yaitu $75 \%$. Karena sebagian besar responden mempunyai BMI normal, maka awareness terhadap kalori pada makanan cepat saji rendah. Responden mempersepsikan bahwa konsumsi fast food dalam jumlah banyak tidak membawa dampak terhadap kenaikan berat badan. Begitu pula pada responden yang mempersepsikan citra tubuhnya negatif juga cenderung mengkonsumsi fast food. Berdasarkan penelitian di Sri Lanka menunjukkan bahwa body image negatif mendorong remaja untuk 
melakukan pembatasan makan tanpa mendapatkan rekomendasi nutritionist dengan tujuan untuk menurunkan berat badan, seperti hanya mengkonsumsi snack dengan tinggi kalori dan melewatkan makanan utama yang tinggi nutrisi ${ }^{[19]}$.

Berdasarkan hasil penelitian ini pendidikan gizi berbsis TPB dapat meningkatkan pengetahuan tentang fast food, menurunkan sikap dan norma subyektif terhadap konsumsi fast food berlebih, serta meningkatkan perceived behavioral control dan intensi untuk membatasi fast food. Penelitian pendidikan gizi berbasis TPB pernah dilakukan pada anak usia sekolah mengenai promosi sarapan, pendidikan gizi dilakukan selama 4 sesi dengan durasi 60 menit, media yang digunakan adalah booklet, berdasarkan penelitian tersebut menunjukkan bahwa pendidikan gizi berbasis TPB dapat meningkatkan pengetahuan, sikap, norma subyektif, perceived behavioral control, dan intensi untuk sarapan [12]. Penelitian pendidikan gizi berbasis TPB juga pernah dilakukan pada siswi SMP di Iran, pendidikan gizi dilakukan selama 4 sesi dengan durasi 40 menit. Sesi pertama dengan cara diskusi, sesi kedua debat, sesi ketiga diskusi, dan sesi keempat diskusi, hasil penelitian tersebut menunjukkan bahwa pendidikan gizi berbasis TPB dapat meningkatkan sikap, norma subyektif, perceived behavioral control, dan intensi untuk mengkonsumsi susu ${ }^{[8]}$.
Berdasarkan hasil penelitian ini pada tabel 2 menunjukkan bahwa sebelum dilakukan pendidikan gizi tidak ada beda pengetahuan $(p=0,936)$, sikap $(p=0,821)$, norma subyektif $(p=0,940)$, perceived behavioral control $(p=0,518)$, niat $(p=0,356)$, dan proporsi asupan $(p=0,780)$ pada kedua kelompok. Sedangkan setelah penelitian pada tabel 2 hasilnya menunjukkan terdapat peningkatan pengetahuan $(p<0,001)$, penurunan sikap terhadap konsumsi fast food $(p<0,001)$, penurunan norma subyektif mengenai konsumsi fast food berlebih $(p=0,016)$, peningkatan perceived behavioral control $(p<0,001)$, dan niat untuk membatasi fast food $(p<0,001)$, tetapi tidak terdapat perbedaan proporsi asupan fast food $(p=0,715)$.

Menurut theory of planned behavior pengetahuan merupakan bagian dari informational dibalik faktor-faktor yang mempengaruhi sikap, norma subyektif, perceived behavioral control, dan intensi ${ }^{[13]}$. Berdasarkan hasil penelitian ini menunjukkan bahwa pendidikan gizi berbasis TPB dapat meningkatkan pengetahuan $(p<0,001)$. Peningkatan pengetahuan yang signifikan merupakan hasil dari pendidikan gizi yang didesain melalui brainstorming dan presentasi materi dari nutrition educator. Dengan metode brainstorming maka akan terlihat poin materi mengenai fast food yang kurang dipahami siswa, sehingga penjelasan melalui presentasi nutrition educator akan membantu

Tabel 2. Distribusi Frekuensi Latar Belakang Responden Kelompok Kontrol dan Intervensi

\begin{tabular}{llcccc}
\hline \multirow{2}{*}{ Latar belakang responden } & & \multicolumn{4}{c}{ Kelompok } \\
\cline { 3 - 6 } & & \multicolumn{2}{c}{ Perlakuan } & \multicolumn{3}{c}{ Kontrol } \\
\cline { 3 - 6 } & & Jumlah & (\%) & Jumlah & (\%) \\
\hline Usia & 15 & 10 & 6,3 & 0 & 0 \\
& 16 & 4 & 25,5 & 7 & 43,8 \\
& 17 & 1 & 6,3 & 9 & 56,3 \\
& 18 & 12 & 75 & 10 & 0 \\
\hline Uang saku & $>$ mean & 4 & 25 & 6 & 37,5 \\
\hline Body image & - mean & 12 & 75 & 12 & 75 \\
& Positif & 4 & 25 & 4 & 25 \\
\hline
\end{tabular}


meningkatkan pengetahuan. Hasil penelitian ini sejalan dengan penelitian yang dilakukan di Iran pada anak usia sekolah mengenai promosi sarapan, berdasarkan hasil penelitian tersebut terdapat peningkatan pengetahuan $(p=0,013)$ setelah dilakukan edukasi, peningkatan pengetahuan pada penelitian tersebut dilakukan melalui metode presentasi oleh nutrition educator dan sesi tanya jawab ${ }^{[12]}$. Hasil penelitian tersebut sejalan dengan penelitian pendidikan kesehatan yang dilakukan pada wanita hamil untuk pencegahan urinary infection, hasil dari penelitian tersebut bahwa terdapat peningkatan pengetahuan $(p<0,001)$ setelah dilakukan edukasi, peningkatan pengetahuan pada penelitian tersebut dilakukan melalui metode presentasi oleh nutrition educator ${ }^{[14]}$.

Sikap merupakan disposisi seseorang dalam merespon sesuatu yang bersifat evaluatif ${ }^{[13]}$. Ketika individu memiliki evaluasi perilaku yang bersifat positif maka individu akan cenderung bersifat favorable. Hasil penelitian ini adalah bahwa pendidikan gizi dapat menurunkan sikap terhadap konsumsi fast food berlebih, dengan penurunan sikap tersebut maka seseorang akan bersikap favorable ketika membatasi fast food. Penurunan sikap terhadap fast food berlebih pada penelitian ini dilakukan dengan cara praktikum membandingkan kalori fast food dengan kalori pada minyak, gula, garam, dan margarin. Dengan menghitung, menimbang, dan membandingkan kalori maka timbul sikap negatif terhadap konsumsi fast food berlebih.

Sebagaimana dapat dilihat pada Tabel 3, perubahan sikap, penelitian pendidikan gizi bertema nutritional preventive sebagai upaya pencegahan DM tipe 2 pada remaja putri menunjukkan bahwa terdapat perubahan sikap $(p<0,001)$ setelah edukasi pada kelompok perlakuan, perubahan sikap pada penelitian tersebut dilakukan melalui metode presentasi pemaparan mengenai penyakit DM tipe 2, sehingga responden bersikap positif terhadap pencegahan DM tipe $2^{[15]}$. Hasil penelitian tersebut sejalan dengan penelitian yang dilakukan pada siswi yang mengalami obesitas, bahwa terdapat perbedaan sikap sesudah $(p<0,001)$ edukasi pada kelompok kontrol dan perlakuan ${ }^{[16]}$.
Norma subyektif merupakan persepsi individu terhadap tekanan lingkungan sosial untuk menunjukkan atau tidak menunjukkan suatu perilaku ${ }^{[13]}$. Norma subyektif didasarkan oleh belief yang disebut normative belief, mengenai kesetujuan atau tidak yang berasal dari referent atau orang dan kelompok yang berpengaruh bagi individu terhadap suatu perilaku. Hasil penelitian ini terdapat perubahan norma subyektif. Penurunan norma subyektif terhadap tren konsumsi fast food berlebih dilakukan melalui pemilihan miss nutrition educator, responden yang terpilih menjadi miss nutrition educator diberikan tugas untuk mengedukasi lingkungan sosialnya, selain itu metode yang dilakukan untuk merubah norma subyektif adalah melalui chatting grup sosial media, chatting melalui grup sosial media dilakukan sebagai upaya membentuk lingkungan sosial yang kondusif terhadap dukungan pembatasan fast food. Berkaitan dengan norma subyektif, suatu penelitian tentang edukasi sarapan pada anak usia sekolah menunjukkan bahwa pendidikan gizi berbasis TPB dapat meningkatkan norma subyektif $(p<0,001)$ pada kelompok intervensi, perubahan norma subyektif dilakukan dengan cara mengundang wali murid, dengan mengundang wali murid maka tujuan program sarapan anak usia sekolah yang umumnya dipersiapkan oleh wali murid dapat tercapai ${ }^{[12]}$. Hasil penelitian tersebut sejalan dengan penelitian mengenai efektivitas pendidian gizi nutritional prevention terhadap diabetes type-2 pada remaja perempuan, setelah edukasi menunjukkan bahwa terdapat perbedaan norma subyektif pada kelompok perlakuan, perubahan norma subyektif dilakukan malalui kegiatan workshop dan peer interaction ${ }^{[15]}$.

Berdasarkan buku Attitude, Personality and Behavior, Ajzen menjelaskan bahwa perceived behavioral control merupakan kesanggupan seseorang untuk menunjukkan tingkah laku yang diinginkan ${ }^{[13]}$. Semakin individu merasakan banyak faktor pendukung dan sedikit penghambat untuk dapat melakukan suatu perilaku, maka individu akan cenderung mempersepsikan diri untuk mudah melakukan perilaku tersebut. Hasil penelitian ini menunjukkan bahwa terdapat perubahan 
PBC, perubahan PBC dilakukan melalui brainstorming dan edukasi problem-solving untuk menjaring ide mengenai permasalahan ketika membatasi fast food dan strategi untuk mengatasi permasalahan. Melalui metode brainstorming maka ditemukan strategi untuk membatasi fast food, sehingga responden semakin merasa sanggup untuk membatasi fast food, dengan demikian maka terjadi perubahan PBC. Berdasarkan hasil penelitian mengenai edukasi pengaturan diet pada siswi obesitas bahwa terdapat perubahan perceived behavioral control $(p<0,001)$ setelah dilakukan edukasi, perubahan PBC dilakukan melalui kegiatan belanja bahan-bahan makanan rendah kalori sebagai upaya penurunan masalah obesitas, dengan kegiatan belanja maka responden akan yakin mengkonsumsi makanan rendah kalori hasil belanjanya ${ }^{[16]}$. Hasil penelitian tersebut sejalan dengan penelitian yang dilakukan pada remaja perempuan preventive nutritional sebagai upaya pencegahan diabetes tipe- 2 yang menunjukkan bahwa terdapat perbedaan perceived behavioral control $(p<0,001)$ sebelum dan sesudah edukasi pada kelompok perlakuan ${ }^{[15]}$.

Berdasarkan Theory of Planned Behavior intensi dapat meramalkan secara akurat berbagai kecenderungan perilaku ${ }^{[13]}$. Menurut Schiffman, intensi merupakan kecenderungan seseorang untuk melakukan suatu tindakan atau perilaku tertentu ${ }^{[17]}$. Berdasarkan hasil penelitian ini menunjukkan bahwa terdapat peningkatan intensi $(p<0,001) \quad$ untuk membatasi fast food pada kelompok perlakuan sebelum dan sesudah edukasi. Perubahan intensi pada kelompok perlakuan merupakan hasil dari edukasi berupa diskusi, dengan berdskusi maka responden merasa termotivasi sehingga intensi untuk membatasi fast food meningkat. Hasil penelitian tersebut sejalan dengan penelitian yang dilakukan pada siswi mengenai edukasi konsumsi susu, berdasarkan hasil penelitian tersebut menunjukkan bahwa terdapat perbedaan niat $(p<0,001)$ antara kelompok kontrol dan perlakuan setelah diberikan edukasi ${ }^{[8]}$. Hasil penelitian tersebut sejalan dengan penelitian yang dilakukan pada remaja perempuan mengenai nutritional prevention diabetes tipe- 2 yang menunjukkan bahwa terdapat peningkatan niat sebelum dan sesudah edukasi gizi pada kelompok perlakuan [15].

Konsumsi fast food dihitung berdasarkan proporsi kalori fast food yang dibandingkan kalori konsumsi harian. Berdasarkan hasil penelitian ini menunjukkan bahwa tidak terdapat perubahan konsumsi fast food $(p=0,057)$. Nilai mean proporsi kalori fast food sebelum edukasi pada kelompok perlakuan adalah $25,71 \%$ setelah edukasi 25,22\%, meskipun terjadi penurunan tetapi tidak terjadi perubahan proporsi konsumsi fast food. Sedangkan pada kelompok kontrol pre-test proporsi kalori fast food adalah $24,96 \%$ pada post-test $27,90 \%$, dapat dilihat bahwa proporsi kalori fast food kelompok kontrol mengalami peningkatan. Hasil penelitian tersebut tidak sejalan dengan penelitian yang dilakukan pada siswa mengenai edukasi sarapan, terjadinya perubahan perilaku sarapan $(p=0,007)$ setelah diberikan intervensi sebanyak 5 sesi dengan durasi 60 menit setiap sesinya ${ }^{[12]}$. Tidak terdapatnya perubahan secara signifikan pada penelitian ini dapat terjadi karena edukasi hanya dilakukan selama 4 sesi, selain itu remaja merupakan usia yang mudah mengikuti sesuatu yang dianggap tren, termasuk tren konsumsi fast food ${ }^{[2]}$.

Kelebihan dari penelitian edukasi pembatasan fast food adalah belum pernah dilakukan di didaerah tersebut, selain itu kelebihan penelitian ini adalah metode yang dilakukan setiap sesinya bervariasi tidak hanya Kelebihan dari penelitian edukasi pembatasan fast food adalah belum pernah dilakukan di didaerah tersebut, selain itu

kelebihan penelitian ini adalah metode yang dilakukan setiap sesinya bervariasi tidak hanya ceramah satu arah, tetapi lebih menekankan pada kegiatan yang banyak melibatkan responden dan nutrition educator hanya bertindak sebagai fasilitator. Kekurangan penelitian ini adalah hanya dilakukan selama 4 sesi, sehingga kurang efektif untuk merubah perilaku konsumsi siswi secara berkelanjutan. 
Tabel 3. Perbandingan Kelompok Kontrol dan Intervensi sebelum dan sesudah intervensi

\begin{tabular}{|c|c|c|c|c|}
\hline \multirow[t]{2}{*}{ Variabel } & \multirow[t]{2}{*}{ Kelompok } & \multirow{2}{*}{$\begin{array}{c}\text { Pre-test } \\
\text { Mean } \pm \text { SD }\end{array}$} & Post-test & \multirow{2}{*}{$\begin{array}{l}\text { Wilcoxon } \\
\text { Signed Ranks }\end{array}$} \\
\hline & & & Mean \pm SD & \\
\hline \multirow[t]{3}{*}{ Pengetahuan } & Perlakuan & $65,33 \pm 8,83$ & $82,00 \pm 11,46$ & 0,001 \\
\hline & Kontrol & $64,29 \pm 12,83$ & $62,86 \pm 11,38$ & 0,317 \\
\hline & Mann-Whitney & 0,936 & 0,000 & \\
\hline \multirow[t]{3}{*}{ Sikap } & Perlakuan & $144,80 \pm 11,73$ & $101,53 \pm 14,54$ & 0,001 \\
\hline & Kontrol & $141,50 \pm 19,56$ & $140,64 \pm 19,27$ & 0,972 \\
\hline & Mann-Whitney & 0,821 & 0,000 & \\
\hline \multirow[t]{3}{*}{ Norma Subyektif } & Perlakuan & $113,53 \pm 17,25$ & $113,53 \pm 17,25$ & 0,002 \\
\hline & Kontrol & $112,43 \pm 19,94$ & $114,50 \pm 21,01$ & 0,374 \\
\hline & Mann-Whitney & 0,940 & 0,016 & \\
\hline \multirow{3}{*}{$\begin{array}{l}\text { Perceived } \\
\text { Behavioral Control }\end{array}$} & Perlakuan & $7,20 \pm 3,68$ & $19,00 \pm 4,52$ & 0,001 \\
\hline & Kontrol & $6,93 \pm 3,83$ & $6,36 \pm 2,62$ & 0,197 \\
\hline & Mann-Whitney & 0,518 & 0,000 & \\
\hline \multirow[t]{3}{*}{ Niat } & Perlakuan & $5,40 \pm 2,06$ & $9,67 \pm 1,95$ & 0,001 \\
\hline & Kontrol & $4,71 \pm 1,81$ & $4,21 \pm 1,42$ & 0,257 \\
\hline & Mann-Whitney & 0,356 & 0,000 & \\
\hline \multirow{3}{*}{$\begin{array}{l}\text { Konsumsi Fast } \\
\text { food }\end{array}$} & Perlakuan & $26,61 \pm 5,70$ & $28,43 \pm 8,18$ & 0,609 \\
\hline & Kontrol & $26,56 \pm 6,13$ & $29,31 \pm 4,98$ & 0,245 \\
\hline & Mann-Whitney & 0,780 & 0,715 & \\
\hline
\end{tabular}

\section{KESIMPULAN}

Pendidikan gizi berbasis theory of planned behavior efektif dalam mempengaruhi pengetahuan, sikap, norma subyektif, perceived behavioral control dan intensi untuk membatasi fast food, tetapi tidak mempengaruhi perilaku pembatasan konsumsi fast food. Kepada peneliti selanjutnya diperlukan inovasi instrumen, media, dan konsep rancangan intervensi dalam pendidikan gizi sehingga tujuan pendidikan gizi sebagai kegiatan untuk merubah suatu perilaku khususnya pembatasan fast food dapat tercapai. Kepada pihak sekolah khususnya pihak pengelola usaha kesehatan sekolah (UKS) diperlukan inovasi kegiatan edukasi atau pendidikan gizi yang berkelanjutan untuk mencegah terjadinya permasalahan gizi dan meningkatkan awereness siswa SMA. Dengan pendidikan gizi yang berkelanjutan maka permasalahan gizi pada siswa SMA dapat dicegah.

\section{ACKNOWLEDGEMENT}

Peneliti mengucapkan terimakasih kepada kepala sekolah SMA 2 Sidoarjo yang telah mengizinkan penelitian, siswi SMA 2 Sidoarjo yang telah bersedia menjadi responden, serta teman saya Alivia Norma yang bersedia membantu peneliti melaksanakan pendidikan gizi.

\section{REFERENSI}

1. Suswanti, Ika. Faktor-faktor yang berhubungan dengan pemilihan makanan cepat saji pada mahasiswa fakultas kedokteran dan ilmu kesehatan 
UIN Syarif Hidayatullah Jakarta. Skripsi. Jakarta: Universitas Islam Negeri Syarif Hidayatullah. Available form $<$ http://repository.uinjkt.ac.id/dspace/bi tstream/123456789/25931/1/IKA\%20SU SWANTI-fkik.pdf> 2012. p. 25

2. Al Faris NA, Al Tamimi J. Trends of Fast Food Consumption Among Adolescent and Young Adult Saudi Girls Living in Riyadh. Article Food and Nutrition Research 2015;59:26488. Available form:

$<$ https://www.ncbi.nlm.nih.gov/pubmed /25792229. Diakses tanggal 3 Maret 2017.

3. Kumar H, Palaha R, Kaur A. Study of Consumption, Behavior and Awareness of Fast Food Among University Hostlers. Asian Journal of Clinical Nutrition 2013;5(1):1-7. Available form: < http://scialert.net/fulltext/?doi=ajcn.20 13.1.7\& org=11> [Diakses 3 Maret 2017].

4. Majabadi HA, Solhi M. Factors Influencing Fast Food Consumption Among Adolescents in Tehran:A Qualitative Study. University of Medical Science. Iran Red Crescent Medical Journal 2016;18(3):e23890 Available form:

$<$ www.ncbi.nlm.nih.gov/pmc/articles/P MC4884438> Diakses 3 Maret 2017.

5. Otemuyiwa IO, Adewusi SRA. Effect of Fast food Consumption on Nutrient Intake among Nigerian Elite in Lagos Nigeria. Departemen of Chemistry, Obafemi Awolowo University.. Int Journal Health Nutrition 2012;3(2): 1219. Available form $;<$ https://scholar.oauife.edu.ng/sadewus i/publications/effects-fast-foodconsumption]-nutrient-intake-amongnigerian-elite-lagos-niger> Diakses 3 Maret 2017.

6. Johnson S, Sahu R, Saxena P. Nutritional Analysis of Junk Food. Centre for Science and Environment 2012. CSE/PML/PR41/2012. Available form: <http http://www.cseindia.org /userfiles /Nutritional_Analysis_Junk_Food.pdf.> Diakses 3 Maret 2017.
7. Arya G, Mishra S. Effects of Junk Food and Beverages on Adolescents Health-A review Article. Journal of Nursing and Health Science 2013;1: Issue (6Juli-Aug): PP 26-32. Available form $<$ http://iosrjournals.org/iosrjnhs/papers/vol1issue6/F0162632. pdf?id $=6560>$ Diakses 3 Maret 2017

8. Baboli GA., Toranjinejad A., Gilasi RH, Moravejy SA, Gharlipour Z, Ramezani T. Effect of Educational Program on Milk Consumption based on the Theory of Planned Behavior among Girls Students. International Journal Pediatric 2017;5(40):4793-4802. Available form < http://ijp.mums.ac.ir/article_7707_d62f 1e343 365f5d56607dc3dd89a0a31.pdf> Diakses 26 April 2017.

9. Pooreh, S., Nodeh, Z, H. Impact of Education Based on Theory of Planned Behavior: An Investigation into Hypertention Preventive Self-care Behaviors in Iranian Girl Adolescent. Iran Journal Public Health 2015;44(6):839847. Available form : https://www.ncbi.nlm.nih.gov/pmc/artic les/PMC4524309/pdf/IJPH-44-839.pdf [diakses 3 Maret 2017].

10. Meena M., Varma K. Fast Food Consumption Among Adolescent School Girls In Jaipur. International Journal of Innovative Research and Review 2015. Volume 3 (3): pp 38-42. Available form : $<$ http://www.cibtech.org/J-InnovativeResearchReview/Publications/2015/VOL-3-NO3/06-JIRR-008-MINALI-FAST-JAIPUR.pdf> Diakses 12 Juli 2017.

11. Madhavi AVP, Nirmalie MI, Rajapaksa RCW, Chandralatha MMAR, Kumari WMSU, Chandana, L. Body Image Perception and Dietary Patterns Among Teenage Girls. Journal of Nursing 2010;1:1-4. Tersedia di < http://www.ou.ac.lk/ours/wpcontent/uploads/2017/05/NSC-43Formatted-checked.pdf $>$. [diakses 12 Juli 2017].

12. Hosseini Z, Aghamolaei T, Gharghani GZ, Ghanbarnejad A. Effect of Educational 
Interventions based on Theory of Planned Behavior to Promote Breakfast Consumption Behavior in students. Hormogzan Medical Journal 2014;19(1): 35-43. Available form: <hmj-v19n1p35en\%20(3).pdf> [diakses 3 Maret 2017].

13. Ajzen, I. Organizational of Behavior and Human Decision Processes. University of Massachusetts at Amherst 1991. Available form: https://pdfs.semanticscholar.org/6256/c a4853f44ab9acb98f91f0d7848c54185ca 7.pdf. Diakses tanggal 3 Maret 2017.

14. Jalali M, Shamsi M, Roozbehani N, Kabir K. Investigation of Health Education Based on Behavioral Promotion of Urinary Infection Prevention in Pregnant Woman. World Journal of Medicine Sciences 2014;11(4):452-460. Available form https://www.idosi.org/wjms/11(4)14/4. pdf> [diakses 12 Juli 2017].

15. Maleki F, Nodeh AH, Rahnavard Z, Arab $M$. Effectiveness of Training on Preventive Nutritional Behaviors for Type-2 Diabetes Among the Female Adolescents : Examination of Theory of Planned Behavior. Medical Journal of the Islamic Republic of Iran 2016;30:340349. Available form : < https://www.ncbi.nlm.nih.gov/pmc/artic les/PMC4898877/pdf/mjiri-30-349.pdf > Diakses 26 April 2017].

16. Soorgi Z, Miri M, Sharifzadeh G. The Impact of Planned Behavior TheoryBased Education on Female Students Obesity-Related Behaviors. Modern Care Journal 2015;12(4):72-86. Available from http://mcjbums.com/en/articles/8672.h tml. diakses 10 Juli 2017.

17. Schiffman, L,G., Leslie, L,K.. Perilaku Konsumen Edisi Kedua. Jakarta : PT. Indeks Gramedia 2007;47-83

18. Fortin, B., Yazbeck, M. Peer Effects, Fast Food Consumption and Adolescent Weight Gain. Journal Research Industral Allience 2015;15(7):1-40. Available from https://www.ncbi.nlm.nih.gov/pubmed/ 25935739. diakses 12 Juli 2017.

19. Madhavi, A, V, P., Nirmalie, M, I., Rajapaksa R, C, W., Chandralatha, $M, M$, A, R., Kumari, W,M,S, U., Chandana, L. Body Image Perception and Dietary Patterns Among Teenage Girls. Journal of Nursing 2010;1:1-4. Available from http://www.ou.ac.lk/ours/wpcontent/uploads/2017/05/NSC-43Formatted-checked.pdf $>$. diakses $12 \mathrm{Juli}$ 2017. 